\title{
Sebaran Populasi dan Klasifikasi Resistensi Eleusine indica terhadap Glifosat pada Perkebunan Kelapa Sawit di Kabupaten Deli Serdang
}

\author{
Population Distribution and Resistance Classification of Eleusine indica to Glyphosate \\ on Oil Palm Plantations in Deli Serdang Regency \\ Koko Tampubolon ${ }^{* 1)}$, Edison Purba ${ }^{2)}$, Diana Sofia Hanafiah ${ }^{2)}$, Mohammad Basyuni ${ }^{3)}$ \\ 1) Program Doktor Ilmu Pertanian, Fakultas Pertanian, Universitas Sumatera Utara \\ 2) Program Studi Agroteknologi, Fakultas Pertanian, Universitas Sumatera Utara \\ 3) Program Studi Kehutanan, Fakultas Kehutanan, Universitas Sumatera Utara
}

Corresponding author: koko.tampubolon@gmail.com

\begin{abstract}
Eleusine indica populations on oil palm plantations in Deli Serdang Regency have not been reported to be resistant to glyphosate. This study was aimed to report distribution and resistance classification of E. indica population on oil palm plantations in Deli Serdang Regency. The research was conducted on Weed Research Center in Faculty of Agriculture, Universitas Sumatera Utara from October 2016 until August 2017. This research used Randomized Block Design with recommended dose at $720 \mathrm{~g}$ a.i.ha-1 of glyphosate and three replications. Population ESUO (from Politeknik Negeri Medan Ball Field) as a comparison. Data on average survival, mortality, dry weight, resistance classification of E. indica were analyzeds using IBM SPSS Statistics 20 software. The results showed that there were $12 \mathrm{E}$. indica populations classified as glyphosate-resistant (56.52\%), 7 glyphosate-resistant developing (30.43\%), and 4 populations classified as glyphosate-susceptible (13.04\%) with the recommended dose at $720 \mathrm{~g}$ a.i.ha-1 from oil palm plantations in Deli Serdang Regency.
\end{abstract}

Keywords: deli serdang regency, Eleusine indica, glyphosate, resistant

Cite this as: Tampubolon, K., Purba, E., Hanafiah, D. S., \& Basyuni, M. 2018. Sebaran Populasi dan Klasifikasi Resistensi Eleusine indica terhadap Glifosat pada Perkebunan Kelapa Sawit di Kabupaten Deli Serdang. Caraka Tani: Journal of Sustainable Agriculture. 33(2), 146-152. doi: http://dx.doi.org/10.20961/carakatani.v33i2.24300

\section{PENDAHULUAN}

Keberadaan gulma pada areal perkebunan kelapa sawit mengakibatkan kerugian secara ekonomi. Kerugian hasil produksi tanaman yang ditimbulkan oleh gulma lebih besar (32\%) dibandingkan dengan hama (18\%) dan penyakit $(15 \%)$. Namun, apabila tidak dilakukan pengendalian, baik secara fisik, kimia maupun biologi, maka angka kerugian produksi tanaman ini bisa mencapai 69,80\% (Oerke and Dehne, 2004). Pada umumnya pengendalian gulma di perkebunan kelapa sawit dilaksanakan secara kimiawi dengan rotasi pengendalian (pusingan)
3-4 bulan. Setelah perkebunan mengenal penggunaan herbisida terutama glifosat dan parakuat, maka pemakaian kedua herbisida tersebut lebih sering digunakan untuk mengendalikan gulma di areal Tanaman Belum Menghasilkan (TBM), Tanaman Menghasilkan (TM), maupun pembibitan.

Penggunaan herbisida dengan mode of action yang sama secara berulang-ulang dalam periode yang lama dapat menyebabkan gulma menjadi resisten. Apabila gulma tersebut sudah resisten maka pengendalian gulma tersebut menjadi sangat sulit (Purba, 2009). Salah satu spesies gulma yang sudah mengalami resisten-glifosat

\footnotetext{
* Received for publication September 29, 2018

Accepted after corrections October 2, 2018
} 
diperkebunan kelapa sawit adalah rumput belulang (Eleusine indica (L.) Gaertn). Gulma ini tergolong agresif karena pertumbuhannya yang kuat dan dapat menghasilkan biji yang melimpah. Gulma belulang dapat tumbuh mencapai 3 kaki atau 1 meter dan menyebar dengan memperbanyak diri melalui biji (Uva et al., 1997). Gulma ini berbunga sepanjang tahun dan tiap rumpun dapat menghasilkan hingga 140.000 biji (Chin, 1979).

Keberadaan E. indica resisten terhadap herbisida glifosat telah dilaporkan diperkebunan kelapa sawit di Sumatera Utara. Berdasarkan Hasil penelitian Lubis et al. (2012) menunjukkan bahwa populasi E. indica dari Kebun Adolina Serdang Bedagai telah resisten terhadap glifosat sebesar 7 kali dibandingkan populasi sensitif. Penelitian Dalimunthe et al. (2015) menyatakan bahwa populasi $E$. indica yang berasal dari Kebun Adolina Serdang Bedagai terbukti telah berkembang menjadi resisten ganda terhadap glifosat dan parakuat. Tingkat resistensi terhadap glifosat sebesar 7,5 kali dibandingkan populasi sensitif. Selain itu Rahmadhani et al. (2016) juga melaporkan bahwa populasi $E$. indica dari Kebun Sei Daun Labuhan Batu Selatan telah resistenglifosat sebesar 6,3 kali, E. indica dari Kebun Adolina Serdang Bedagai telah resisten-glifosat sebesar 16,7 kali, E. indica dari Kebun Galang Serdang Bedagai telah resisten-glifosat sebesar 5,2 kali, E. indica dari Kebun Rambutan Serdang Bedagai telah resisten-glifosat sebesar 5,8 kali, dan E. indica dari Kebun Sawit Seberang Langkat telah resisten-glifosat sebesar 5,1 kali. Penelitian Syahputra et al. (2016) melaporkan populasi $E$. indica dari Blok Afdeling 1 sampai 9 di Kebun Adolina Serdang Bedagai sudah resisten-glifosat sebanyak 57 populasi $(98,28 \%)$ dan 1 populasi berkembang resisten glifosat $(1,72 \%)$.

Populasi E. indica yang berasal dari perkebunan kelapa sawit di Kabupaten Deli Serdang belum ada dilaporkan mengalami resistensi terhadap herbisida glifosat. Kabupaten Deli Serdang pada tahun 2015 mempunyai luas lahan kelapa sawit yang terdiri dari perkebunan negara (14.373 ha), swasta (20.668 ha) dan rakyat (14.561 ha) (Direktorat Jenderal Perkebunan, 2017). Untuk itu diperlukan laporan awal sebaran populasi $E$. indica resisten-glifosat sebagai sumber informasi dalam mengendalikan gulma tersebut. Tujuan penelitian ini adalah untuk melaporkan sebaran populasi dan mengklasifikasi resistensi $E$. indica terhadap glifosat pada perkebunan kelapa sawit di Kabupaten Deli Serdang.

\section{METODE PENELITIAN}

\section{Pengambilan Biji Populasi Resisten dan Sensitif Eleusine indica}

Biji populasi $E$. indica yang resisten dikoleksi dari perkebunan kelapa sawit di Kabupaten Deli Serdang (Table 1) dengan kriteria biji yang sudah matang ditandai warna malai sudah kecokelatan sebanyak 50 rumpun per lokasi. Pengambilan biji gulma yang sensitif $\left(\mathrm{ESU}_{0}\right)$ diambil dari Lapangan Bola Politeknik Negeri Medan, dimana herbisida tidak pernah diaplikasikan sebelumnya. Penelitian ini dilaksanakan pada bulan Oktober 2016 sampai dengan Agustus 2017.

\section{Perendaman Biji}

Benih gulma terlebih dahulu direndam dalam larutan kalium nitrat $\left(\mathrm{KNO}_{3}\right)$ dengan konsentrasi 0,2\% selama 30 menit (Ismail et al., 2002). Perendaman ini bertujuan untuk mematahkan dormansi sekunder biji E. indica.

\section{Pengecambahan dan Pindah Tanam}

Media kecambah yang digunakan adalah topsoil dan pupuk kandang yang sudah diayak dengan perbandingan volume 1:1. Setelah dicampur secara merata, media diovenkan dengan suhu $100^{\circ} \mathrm{C}$ selama 3 jam kemudian dimasukkan kedalam bak perkecambahan yang berukuran $33 \times 24 \mathrm{~cm}$ dan sudah diberi kode sumber lokasi pengambilan sampel. Penanaman pada bak kecambah dilakukan di rumah plastik lahan percobaan Fakultas Pertanian, Universitas Sumatera Utara. Media perkecambahan disemprot dengan insektisida untuk mencegah serangan semut merah terhadap biji gulma. Penyiraman dilakukan pada sore hari dengan menggunakan gembor yang lubangnya halus agar akar bibit tidak terbongkar dari media tanam.

Setelah bibit $E$. indica berdaun 2-3 helai, bibit dipindah tanam kedalam pot dengan media tanam topsoil, pasir dan pupuk kandang yang sudah diayak dengan perbandingan volume 1:1:1. Jumlah bibit $E$. indica yang dipindahkan sebanyak 10 bibit per pot dan ditanam secara menyebar merata. Setelah tanam-pindah kemudian dipelihara ditempat berbeda di Lahan Pusat Penelitian Gulma Fakultas Pertanian, Universitas Sumatera Utara. Penyiraman dilakukan pada sore 
hari dengan menggunakan gembor yang lubangnya halus.

Table 1. E. indica population was taken on several estates in Deli Serdang Regency

\begin{tabular}{cccl}
\hline No. & $\begin{array}{c}\text { Kode } \\
\text { Sampel }\end{array}$ & Afdeling & \multicolumn{1}{c}{ Nama Kebun } \\
\hline 1 & ESU1.16 & 4 & $\begin{array}{l}\text { Kebun Tanjung Garbus } \\
\text { Pagar Merbau }\end{array}$ \\
2 & ESU1.17 & 2 & Kebun Jati Baru \\
3 & ESU1.18 & 1 & Kebun Tamora \\
4 & ESU1.19 & 1 & Kebun Bandar Klippa \\
5 & ESU1.20 & 1 & Kebun Sampali \\
6 & ESU1.21 & 2 & Kebun Sampali \\
7 & ESU1.22 & 4 & Kebun Saentis \\
8 & ESU1.23 & 2 & Kebun Kelambir Lima \\
9 & ESU1.24 & 3 & Kebun Klumpang \\
10 & ESU1.25 & 2 & Kebun Tandem Hilir \\
11 & ESU1.26 & 1 & Kebun Kwala Bekala \\
12 & ESU1.27 & 1 & Kebun Batang Kuis \\
13 & ESU1.28 & 2 & Kebun Batang Kuis \\
14 & ESU1.29 & 3 & Kebun Helvetia \\
15 & ESU1.30 & 1 & Kebun Limau Mungkur \\
16 & ESU1.31 & 2 & Kebun Limau Mungkur \\
17 & ESU1.32 & 2 & Kebun Sei Semayang \\
18 & ESU1.33 & 1 & Kebun Patumbak \\
19 & ESU2.1 & 3 & Kebun Sei Putih \\
20 & ESU5.3 & 1 & Kebun Bagerpang \\
21 & ESU5.4 & 2 & Kebun Bagerpang \\
22 & ESU5.5 & - & Kebun Sei Merah \\
23 & ESU7.1 & 2 & Kebun Timbang Deli \\
\hline
\end{tabular}

\section{Aplikasi Herbisida Glifosat}

Setiap pot E. indica dari lokasi yang berbeda disusun dengan rancangan acak kelompok (RAK) dan tiga ulangan. Gulma tersebut disemprot herbisida glifosat dengan dosis rekomendasi $720 \mathrm{~g} \mathrm{~b}$ a.ha ${ }^{-1}$ (Round-up $486 \mathrm{SL}$ ). Volume semprot yang diperoleh $2921 \mathrm{ha}^{-1}$. Penyemprotan glifosat dilakukan saat E. indica berdaun 3-4 helai (Hess et al., 1997). Penyemprotan dilakukan pada waktu cuaca cerah dan diusahakan mengenai seluruh tajuk gulma.

\section{Pengamatan dan Analisis Statistik}

Parameter yang diamati antara lain: mortalitas, jumlah $E$. indica bertahan hidup, bobot kering dan klasifikasi resistensi. Pengamatan mortalitas, jumlah E. indica bertahan hidup, dan klasifikasi resisten dilakukan pada 21 hari setelah aplikasi (HSA) (Jalaludin et al., 2015). Gulma E. indica yang hidup sampai minggu ke-6 setelah aplikasi, dipotong tepat pada leher akar (permukaan tanah) dari masing-masing pot. Kemudian dioven pada temperatur $80^{\circ} \mathrm{C}$ selama 48 jam (SERAS, 1994) untuk memperoleh bobot kering yang konstan. Klasifikasi resistensi diukur dari persentase populasi gulma yang bertahan hidup. Klasifikasi sensitif ( $S$ ) jika persentase populasi gulma bertahan hidup $<2,00 \%$, klasifikasi berkembang resisten (BR) jika persentase populasi gulma bertahan hidup 2,00 - <20,00\%, dan klasifikasi resisten (R) jika persentase populasi gulma bertahan hidup $\geq 20 \%$ (Owen dan Powles, 2009). Pengujian penelitian ini menggunakan rataan dengan software IBM SPSS Statistics 20.

\section{HASIL DAN PEMBAHASAN}

Populasi E. indica yang bertahan hidup terhadap aplikasi glifosat $720 \mathrm{~g}$ b.a.ha ${ }^{-1}$ dari perkebunan kelapa sawit di Kabupaten Deli Serdang ditunjukkan pada Figure 1. Diperoleh populasi E. indica sebanyak 12 dari 23 populasi yang menunjukkan potensi resisten terhadap glifosat pada dosis $720 \mathrm{~g}$ b.a.ha ${ }^{-1}$ dengan presentase $E$. indica yang bertahan hidup berkisar $21,85-90,00 \%$, populasi yang tergolong berkembang resisten-g lifosat berkisar 3,33$16,67 \%$ sebanyak 7 populasi dan sensitif-glifosat sebanyak 4 populasi.

Hal ini disebabkan terjadinya pemakaian glifosat secara terus-menerus untuk mengendalikan gulma di perkebunan kelapa sawit yang dapat mengambat enzim EPSPS (5enolpyruvylshikimate-3-phosphate synthase) sehingga resisten-glifosat. Hambatan enzim EPSPS ini terjadi di kloroplas sehingga mengalami peningkatan akumulasi asam shikimat. Hal ini sesuai dengan penelitian Chun et al. (2015) yang menyatakan bahwa enzim EPSPS pada biotipe E. indica resisten-glifosat dari Cina Selatan dengan cepat merespon glifosat dan terdeteksi pada 12 jam setelah terpapar glifosat. Ekspresi mRNA dan protein dari biotipe $E$. indica resisten-glifosat meningkat secara konstan seiring meningkatnya konsentrasi herbisida glifosat. Chen et al. (2015) menyatakan bahwa kandungan klorofil mengalami penurunan sedikit pada daun E. indica resisten-glifosat yang berasal dari Chengdu dan Guangzhou, China. Penelitian Molin et al. (2013) menyatakan bahwa peningkatan kadar asam shikimat pada daun $E$. indica terpapar glifosat yang berasal dari Washington County, Mississippi menunjukkan 
peningkatan resisten lima hingga delapan kali dibandingkan populasi sensitif.

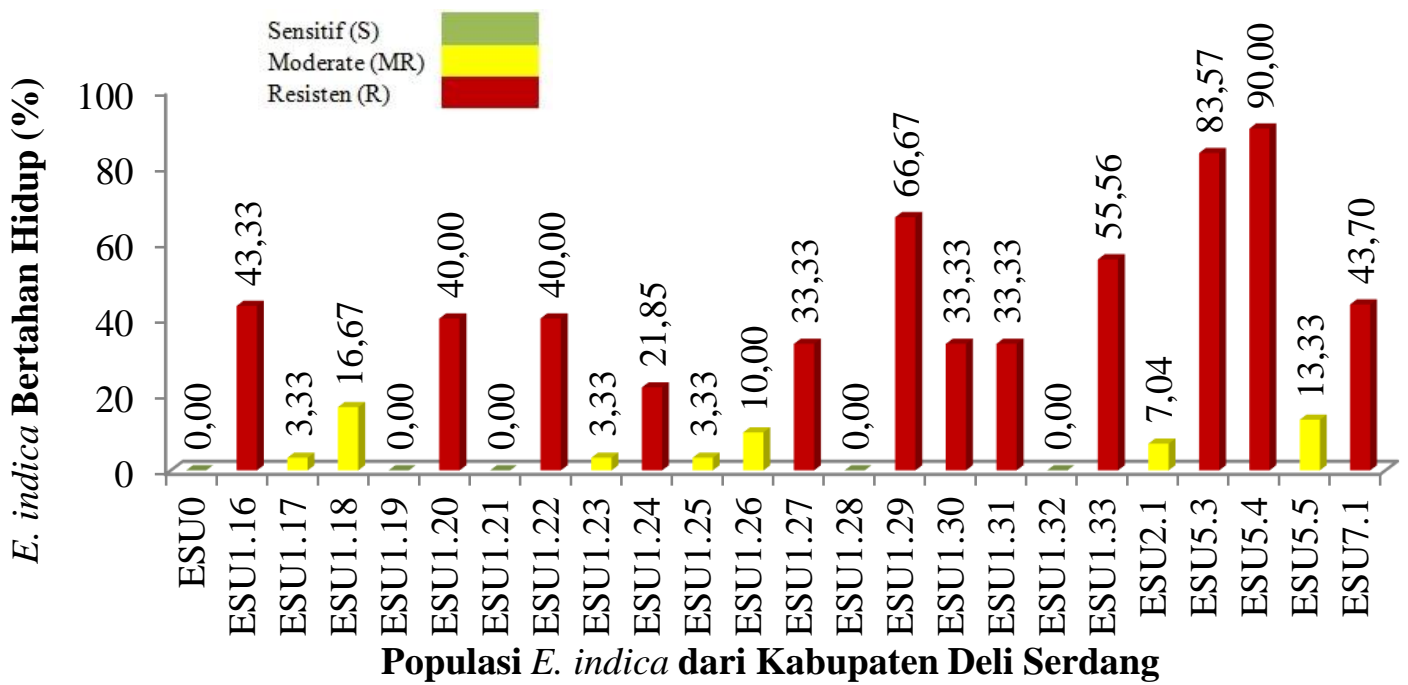

Figure 1. Population of E. indica survival to glyphosate at $720 \mathrm{~g}$ a.i.ha-1 from oil palm plantations in Deli Serdang Regency

Rataan mortalitas, bobot kering dan klasifikasi resistensi $E$. indica dari perkebunan kelapa sawit di Kabupaten Deli Serdang dapat dilihat pada Table 2. Diperoleh bahwa mortalitas dan bobot kering dari 12 populasi E. indica resisten-glifosat dari pada perkebunan kelapa sawit di Kabupaten Deli Serdang berkisar 10,00-78,15\% dan 5,24-18,70 g.

Table 2. Average mortality, dry weight and resistance classification of E. indica from oil palm plantations in Deli Serdang Regency and susceptible populations (ESU $)$

\begin{tabular}{|c|c|c|c|c|c|c|}
\hline \multirow{2}{*}{ No } & \multirow{2}{*}{ Sampel } & \multirow{2}{*}{ Mortalitas (\%) } & \multirow{2}{*}{ Bobot Kering (g/pot) } & \multicolumn{3}{|c|}{ Klasifikasi Resistensi } \\
\hline & & & & $\mathrm{S}$ & $\mathrm{BR}$ & $\mathrm{R}$ \\
\hline 1 & $\mathrm{ESU}_{0}$ (sensitif) & 100,00 & 0,00 & $\sqrt{ }$ & - & - \\
\hline 2 & $\mathrm{ESU}_{1.16}$ & 56,67 & 10,89 & - & - & $\sqrt{ }$ \\
\hline 3 & $\mathrm{ESU}_{1.17}$ & 96,67 & 0,72 & - & $\sqrt{ }$ & - \\
\hline 4 & $\mathrm{ESU}_{1.18}$ & 83,33 & 4,84 & - & $\sqrt{ }$ & - \\
\hline 5 & $\mathrm{ESU}_{1.19}$ & 100,00 & 0,00 & $\sqrt{ }$ & - & - \\
\hline 6 & $\mathrm{ESU}_{1.20}$ & 60,00 & 15,10 & - & - & $\sqrt{ }$ \\
\hline 7 & $\mathrm{ESU}_{1.21}$ & 100,00 & 0,00 & $\sqrt{ }$ & - & - \\
\hline 8 & $\mathrm{ESU}_{1.22}$ & 60,00 & 12,66 & - & - & $\sqrt{ }$ \\
\hline 9 & $\mathrm{ESU}_{1.23}$ & 96,67 & 0,84 & - & $\sqrt{ }$ & - \\
\hline 10 & $\mathrm{ESU}_{1.24}$ & 78,15 & 5,24 & - & - & $\sqrt{ }$ \\
\hline 11 & $\mathrm{ESU}_{1.25}$ & 96,67 & 1,70 & - & $\sqrt{ }$ & - \\
\hline 12 & $\mathrm{ESU}_{1.26}$ & 90,00 & 2,32 & - & $\sqrt{ }$ & - \\
\hline 13 & $\mathrm{ESU}_{1.27}$ & 66,67 & 10,82 & - & - & $\sqrt{ }$ \\
\hline 14 & $\mathrm{ESU}_{1.28}$ & 100,00 & 0,00 & $\sqrt{ }$ & - & - \\
\hline 15 & $\mathrm{ESU}_{1.29}$ & 33,33 & 18,18 & - & - & $\sqrt{ }$ \\
\hline 16 & $\mathrm{ESU}_{1.30}$ & 66,67 & 12,48 & - & - & $\sqrt{ }$ \\
\hline 17 & $\mathrm{ESU}_{1.31}$ & 66,67 & 9,51 & - & - & $\sqrt{ }$ \\
\hline 18 & $\mathrm{ESU}_{1.32}$ & 100,00 & 0,00 & $\sqrt{ }$ & - & - \\
\hline 19 & $\mathrm{ESU}_{1.33}$ & 44,44 & 10,54 & - & - & $\sqrt{ }$ \\
\hline 20 & $\mathrm{ESU}_{2.1}$ & 92,96 & 1,34 & - & $\sqrt{ }$ & - \\
\hline 21 & $\mathrm{ESU}_{5.3}$ & 16,43 & 17,59 & - & - & $\sqrt{ }$ \\
\hline 22 & $\mathrm{ESU}_{5.4}$ & 10,00 & 18,70 & - & - & $\sqrt{ }$ \\
\hline 23 & $\mathrm{ESU}_{5.5}$ & 86,67 & 2,93 & - & $\sqrt{ }$ & - \\
\hline 24 & $\mathrm{ESU}_{7.1}$ & 56,30 & 13,32 & - & - & $\sqrt{ }$ \\
\hline
\end{tabular}

Keterangan : S=Sensitif (<2,00\%); BR=Berkembang Resisten $(2,00-<20,00 \%)$; $R=$ Resisten $(\geq 20,00 \%)($ Owen dan Powles, 2009). 
Populasi E. indica yang tergolong resistenglifosat antara lain $\mathrm{ESU}_{1.16}, \mathrm{ESU}_{1.20}, \mathrm{ESU}_{1.22}$, $\mathrm{ESU}_{1.24}, \mathrm{ESU}_{1.27}, \mathrm{ESU}_{1.29}, \mathrm{ESU}_{1.30}, \mathrm{ESU}_{1.31}$, $\mathrm{ESU}_{1.33}, \mathrm{ESU}_{5.3}, \mathrm{ESU}_{5.4}$ dan ESU $\mathrm{E}_{7.1}$. Populasi $E$. indica yang tergolong berkembang resistenglifosat antara lain $\mathrm{ESU}_{1.17}, \mathrm{ESU}_{1.18}, \mathrm{ESU}_{1.23}$, $\mathrm{ESU}_{1.25}, \mathrm{ESU}_{1.26}, \mathrm{ESU}_{2.1}$ dan ESU 5.5 . Populasi $E$. indica yang tergolong sensitif-glifosat antara lain $\mathrm{ESU}_{1.19}, \mathrm{ESU}_{1.21}, \mathrm{ESU}_{1.28}$ dan ESU $\mathrm{ES}_{1.32}$. Populasi $E$. indica yang memiliki persentase mortalitas yang tertinggi terdapat $\mathrm{ESU}_{5.4}$ (afdeling 2, Kebun Bagerpang) sebesar 10,00\%. Hal ini menunjukkan bahwa penggunaan herbisida glifosat 720 g b.a.ha ${ }^{-1}$ pada perkebunan kelapa sawit di Kabupaten Deli Serdang sudah sering digunakan secara berulang-ulang dalam mengendalikan gulma. Resistensi ini dapat disebabkan oleh perubahan target site dan non target site. Terjadinya perubahan target site pada gulma yang disebabkan glifosat menghambat enzim EPSPS. Hambatan ini mengakibatkan terakumulasinya asam shikimat di jaringan kloroplas. Shikimate-3phoshate (S-3-P) tidak dikonversi menjadi enolpyruvyl-shikimate-3-phosphate (ESPS) sehingga meningkatkan jumlah akumulasi asam shikimat. Peningkatan akumulasi asam shikimat mengakibatkan populasi $E$. indica menjadi resisten. Perubahan non target site secara umum dikarenakan translokasi ${ }^{14} \mathrm{C}$-glifosat ke tajuk lebih rendah. Rendahnya translokasi ${ }^{14} \mathrm{C}$-glifosat pada tajuk gulma membuat bahan aktif herbisida tidak efektif. Hal ini sesuai dengan literatur Nandula et al. (2005) yang menyatakan bahwa terdapat 2 mekanisme resistensi gulma terhadap herbisida glifosat, yaitu mengurangi translokasi herbisida glifosat dan perubahan target site gulma. Hal ini didukung dengan penelitian Alcantara et al. (2016) yang menyatakan bahwa translokasi ${ }^{14} \mathrm{C}$ glifosat ke tajuk E. indica yang terpapar herbisida glifosat sebesar $10,9 \%$ dan di akar sebesar 2,8\%. Perbedaan retensi ${ }^{14} \mathrm{C}$-glifosat pada daun yang terpapar herbisida dan translokasi pada seluruh tajuk dapat menyebabkan resisten glifosat. Selain itu, Monaco et al. (2002) menyatakan bahwa terjadi peningkatan shikimat di jaringan kloroplas disebabkan glifosat. Akumulasi shikimat disebabkan oleh glifosat menghambat enzim EPSPS. EPSPS adalah enzim dalam jalur biosintesis asam amino aromatik yang mengubah shikimate-3-phosphate (S-3-P) menjadi enolpyruvylshikimate-3-phosphate (EPSP) dan akhirnya mengarah pada produksi asam amino, fenilalanin dan tirosin, serta triptofan. Shikimat terbentuk pada perlakuan glifosat karena S-3-P tidak dapat dikonversi menjadi EPSP dan karena S-3-P tidak stabil, maka dikonversi menjadi shikimat yang lebih stabil dan terakumulasi.

Persentase klasifikasi resistensi E. indica dari perkebunan kelapa sawit di Kabupaten Deli Serdang (Figure 2.).

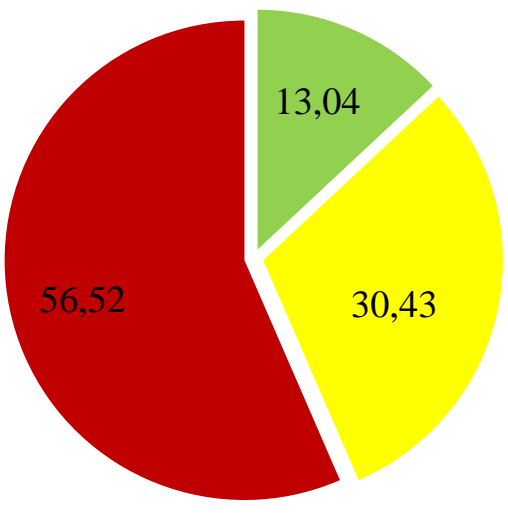

Sensitif (S)
Berkembang Resisten (BR)

Resisten (R)

Figure 2. Percentage of E. indica resistance classification from oil palm plantations in Deli Serdang Regency

Diperoleh dari 23 populasi E. indica yang diaplikasikan glifosat dengan dosis rekomendasi $720 \mathrm{~g} \mathrm{~b} . \mathrm{a} \cdot \mathrm{ha}^{-1}$ yang berasal dari perkebunan kelapa sawit di Kabupaten Deli Serdang, diantaranya terdapat 12 populasi yang tergolong resisten- glifosat $(56,52 \%)$, terdapat 7 populasi yang tergolong berkembang resisten-glifosat $(30,43 \%)$, dan 4 populasi yang tergolong sensitif-glifosat $(13,04 \%)$. Populasi E. indica yang resistenglifosat dari perkebunan kelapa sawit 
di Kabupaten Deli Serdang hanya menguning pada beberapa hari kemudian kembali tumbuh segar, memiliki anakan dan menghasilkan biji pada saat pengamatan visual dilapangan. Hasil penelitian ini membuktikan bahwa penggunaan herbisida glifosat ini sudah mendominasi perkebunan kelapa sawit di Kabupaten Deli Serdang. Beberapa hasil peneliti sebelumnya juga sudah melaporkan $E$. indica resisten-glifosat pada perkebunan kelapa sawit di Sumatera Utara. Penelitian Tampubolon dan Purba, (2018 $)$ melaporkan bahwa E. indica sudah resistenglifosat pada dosis $720 \mathrm{~g}$ b.a.ha ${ }^{-1}$ yang berasal dari perkebunan kelapa sawit di Kabupaten Padang Lawas dan Tapanuli Selatan masing-masing sebesar $36,36 \%$ dan $83,33 \%$. Syahputra et al. (2016) juga melaporkan bahwa populasi $E$. indica juga sudah resisten-glifosat sebesar 98,28\% yang berasal dari Kebun Adolina Serdang Bedagai pada dosis $480 \mathrm{~g}$ b.a.ha ${ }^{-1}$. Tampubolon dan Purba, $\left(2018^{b}\right)$ juga melaporkan $E$. indica sudah resistenglifosat pada dosis $720 \mathrm{~g}$ b.a.ha ${ }^{-1}$ yang berasal dari perkebunan kelapa sawit di Kabupaten Langkat sebesar 42,11\%. Tampubolon et al. (2018) juga melaporkan $E$. indica sudah resisten-glifosat pada dosis $720 \mathrm{~g}$ b.a.ha ${ }^{-1}$ yang berasal dari perkebunan kelapa sawit di Kabupaten Serdang Bedagai sebesar 89,36\%. Berdasarkan persentase klasifikasi resistensi $E$. indica diperkebunan kelapa sawit dari Kabupaten Deli Serdang ini sudah tergolong tinggi. Sedangkan klasifikasi $E$. indica yang tergolong berkembang resistenglifosat ini dikhawatirkan akan mengalami evolusi dan berpotensi menjadi resisten terhadap herbisida glifosat jika masih menggunakan bahan aktif dan dosis yang sama. Kondisi ini sangat mengganggu produksi dan kualitas kelapa sawit.

\section{KESIMPULAN}

Populasi ESU $_{5.4}$ (Afdeling 2 Kebun Bagerpang) memiliki kemampuan bertahan hidup dan bobot kering tertinggi masing-masing sebesar $90,00 \%$ dan 18,70 g. Populasi E. indica yang berasal perkebunan kelapa sawit di Kabupaten Deli Serdang sudah resisten-glifosat sebesar $56,52 \%$ (12 populasi), berkembang resistenglifosat sebesar $30,43 \%$ (7 populasi), dan sensitifglifosat sebesar $13,04 \%$ (4 populasi) pada dosis rekomendasi $720 \mathrm{~g}$ b.a.ha ${ }^{-1}$.

\section{ACKOWLEDGEMENT}

Penulis mengucapkan terima kasih kepada Kementerian Riset, Teknologi dan Pendidikan Tinggi Republik Indonesia yang telah mendanai penelitian ini melalui Program Magister menuju Doktor untuk Sarjana Unggul (PMDSU) dan Fakultas Pertanian Universitas Sumatera Utara serta perkebunan kelapa sawit di Kabupaten Deli Serdang.

\section{DAFTAR PUSTAKA}

Alcantara, R., Fernandez, P., Smeda, R. J., Alves, P. L., \& De Prado, R. 2016. Response of Eleusine indica and Paspalum distichum to glyphosate following repeated use in citrus groves. Crop Protection. 79, 1-7. https://doi.org/10.1016/j.cropro.2015.09.027

Chen, J. C., Huang, H. J., Wei, S. H., Zhang, C. X., \& Huang, Z. F. 2015. Characterization of Glyphosate-Resistant Goosegrass (Eleusine indica) Populations in China. Journal of Integrative Agriculture. 14(5), 919-925. https://doi.org/10.1016/S2095$3119(14) 60910-2$

Chin, H. F. 1979. Weed seed-A Potentional Source of Danger. Proceedings of the Plant Protection Seminar. 22-23 September 1979.

Chun, Z., Li, F., Ting-ting, H., Cai-hong, Y., Guoqi, C., \& Xing-shan, T. 2015. Investigating the Mechanisms of Glyphosate Resistance in Goosegrass (Eleusine indica) Population from South China. Journal of Integrative Agriculture. 14(5), 909-918. https://doi.org/10.1016/S20953119(14)60890-X

Dalimunthe, S. P., Purba, E., \& Meiriani. 2015. Respons Dosis Biotip Rumput Belulang (Eleusine indica L. Gaertn) Resisten-Glifosat terhadap Glifosat, Parakuat dan Indaziflam. Jurnal Online Agroekoteknologi. 3(2),625633.

Direktorat Jenderal Perkebunan. 2017. Statistik Perkebunan Indonesia Komoditas Kelapa Sawit 2015-2017. Kementerian Pertanian, Jakarta.

Hess, M., Barraljs, G., Bleiholder, H., Buhr, L., Eggers, T., Hack, H., \& Stauss, R. 1997. Use of the Extended BBCH Scale - General for the 
Descriptions of the Growth Stages of Monoand Dicotyledonous Weed Species. Weed Research. 37(6), 433-441. https://doi.org/10.1046/j.1365-

3180.1997.d01-70.x

Ismail, B. S., Chuah, T. S., Salmijah, S., Teng, Y. T., \& Schumacher, R. W. 2002. Germination and Seedling Emergence of GlyphosateResistant and Susceptible Biotypes of Goosegrass (Eleusine indica [L.] Gaertn.). Weed Biology and Management. 2(4), 177185. https://doi.org/10.1046/j.14456664.2002.00066.x

Jalaludin, A., Yu, Q., \& Powles, S. B. 2015. Multiple Resistance Across Glufosinate, Glyphosate, Paraquat and ACCase-inhibiting Herbicides in an Eleusine indica Population. Weed Research. 55(1), 82-89. https://doi.org/10.1111/wre.12118

Lubis, L. A., Purba, E.,\& Sipayung, R. 2012. Respons Dosis Biotip Eleusine indica Resisten-Glifosat Terhadap Glifosat, Parakuat, dan Glufosinat. Jurnal Online Agroekoteknologi. 1(1), 109-123.

Molin, W., Wright, A., \& Nandula, V. 2013. Glyphosate-Resistant Goosegrass from Mississippi. Agronomy. 3(2), 474-487. https://doi.org/10.3390/agronomy3020474

Monaco, J. T., Weller, C. S., \& Ashton, M. F. 2002. Weed Science Principles and Practices. Fourth Edition, Jhon Wiley \& Sons. Inc., New York. $685 \mathrm{p}$

Nandula, V. K., Reddy, K. N., Duke, S. O., \& Poston, D. H. 2005. Glyphosate-Resistant Weeds: Current Status and Future Outlook. Outlooks on Pest Management. 16(4), 183187. https://doi.org/10.1564/16aug11

Oerke, E. C., \& Dehne, H. W. 2004. Safeguarding Production-Losses in Major Crops and The Role of Crop Protection. Crop Protection. 23 (4), 275-285. https://doi.org/10.1016/j.cropro.2003.10.001

Owen, M. J., \& Powles, S. B. 2009. Distribution and Frequency of Herbicide-Resistant Wild Oat (Avena spp.) Across the Western
Australian Grain Belt. Crop and Pasture Science. $\quad 60(1)$, 25-31. https://doi.org/10.1071/CP08178

Purba, E. 2009. Keanekaragaman Herbisida dalam Pengendalian Gulma Mengatasi Populasi Gulma Resisten dan Toleran Herbisida. Pidato Pengukuhan Jabatan Guru Besar Tetap Universitas Sumatera Utara Medan.

Rahmadhani, A., Purba, E., \& Hanafiah, D. S. 2016. Respons Lima Populasi Eleusine indica L. Gaertn Resisten-Herbisida Terhadap Glifosat dan Parakuat. Jurnal Online Agroekoteknologi. 4(4), 2245-2254.

SERAS. 1994. Standard operating procedures: Plant Biomass Determination. Scientific Engineering Response and Analytical Services. 1-5. https://doi.org/10.1201/b1441217

Syahputra, A. B., Purba, E., \& Hasanah, Y. 2016. Sebaran Gulma Eleusine indica L. Gaertn Resisten Ganda Herbisida Pada Satu Kebun Kelapa Sawit di Sumatera Utara. Jurnal Online Agroekoteknologi. 4(4), 2407-2419.

Tampubolon, K., \& Purba, E. 2018 ${ }^{\text {a }}$ Screening Single Resistance of Eleusine indica on Oil Palm Plantation in Padang Lawas and Tapanuli Selatan Regency Indonesia. Jurnal Natural. 18(2), 101-106. https://doi.org/10.24815/jn.v18i2.11223.

Tampubolon, K., \& Purba, E. 2018 ${ }^{\text {b }}$. Konfirmasi Resistensi Eleusine indica terhadap Glifosat pada Perkebunan Kelapa Sawit di Kabupaten Langkat. Jurnal Pertanian Tropik. 5(2), 276283.

Tampubolon, K., Purba, E., Basyuni, M., \& Hanafiah, D. S. 2018. Distribution Mapping of Glyphosate-Resistant Eleusine indica in Serdang Bedagai Regency. Jurnal Natural. 18(3), 127-134. https://doi.org/10.24815/jn.v18i1.8649.

Uva, R. H., Neil, J. C., \& DiTomaso, J. M. 1997. Weeds of the Northeast. Ithaca: Cornell University Press. 